\title{
AOR
}

Selected Papers of \#AolR2020:

The 22nd Annual Conference of the

Association of Internet Researchers

Virtual Event / 13-16 Oct 2021

\section{WHAT DEAD-AND-DYING PLATFORMS DO FOR INTERNET STUDIES: SITUATING TECHNOLOGICAL FAILURE, DIGITAL AFTERLIFE, AND THE WEB THAT WAS}

\author{
Muira McCammon \\ Annenberg School for Communication, University of Pennsylvania \\ Lotus Ruan \\ University of Toronto, Canada \\ Kate Miltner \\ University of Edinburgh, United Kingdom \\ Ysabel Gerrard \\ University of Sheffield, United Kingdom \\ Kathryn Montalbano \\ Appalachian State University, United States of America \\ Karolina Mikołajewska-Zając \\ Kozminski University, Poland / University of Queensland, Australia \\ Attila Márton \\ Copenhagen Business School, Denmark
}

This panel explores internet histories through the lens of "platform death" as a way of understanding how digital communities grapple with technological failure, infrastructural absence, and the frailty of digital culture. Collectively, the panelists develop theoretical frameworks to situate the cultural, geopolitical, economic, and socio-legal repercussions of technological failure. As a point of departure, we assume that platforms can bring together a wide set of actors, from couchsurfers to civic technologists, military personnel to civilians, spies to free speech activists; they can serve as a stage where people debate, develop personal relationships, and jockey for divergent futures (Marvin, 1988; Pearce, 2011; Baym, 2015; Lee, 2017; Gillespie, 2018). But what becomes of platforms

Suggested Citation (APA): McCammon, M., Ruan, L., Miltner, K., Gerrard, Y., Montalbano, K., Mikołajewska-Zając, K., Márton, A. (2021, October). What Dead-and-Dying Platforms Do for Internet Studies: Situating Technological Failure, Digital Afterlife, and the Web That Was. Panel presented at AolR 2021: The 22nd Annual Conference of the Association of Internet Researchers. Virtual Event: AolR. Retrieved from http://spir.aoir.org. 
when they fade, fail, or fall from public favor; can they, like software, experience an "afterlife" (Stevenson and Gehl, 2019)? What can dead and dying platforms tell us about technological growth and stagnation, digital present(s) and future(s)?

This panel represents a collaborative effort to complicate, document, and build on the narratives of platform collapse, precarity, and frailty that scholars (Gehl, 2012; Chun, 2016; Belleflamme \& Neysen, 2017; Gomez-Meijia, 2018; Helmond \& van der Vlist, 2019) and tech reporters (Kircher, 2016) have highlighted over the past two decades. Panelists, in their scholarly work and exploration of five different platforms, establish that "platform death" is so much a monolithic or static concept. Indeed, death in the context of digital culture can be understood as an industrial process, as a negotiation between different platform stakeholders, and even, as a discursive marker. As a conceptual framework, it can provide for a rich understanding of how technological failure occurs and ripples across divergent digital communities.

\section{The papers}

In this panel, we provide five arguments that focus on a range of conceptions of platform death.

The first contribution looks at platform counter-narratives and platform countermemories related to a U.S. military-made social media platform, TroopTube. It focuses on the ways in which technological failure can help surface narratives of contestation and power struggles between engineers, users, and other stakeholders invested in a specific platform's design.

The second contribution examines Fanfou, a Chinese platform launched in 2007. It examines two intertwined questions: How does China's regulatory environment affect the development and evolution of niche social media platforms, and how do small and surviving platforms and their users adjust their operation strategies and social media use in response to state control?

The third contribution offers a nostalgic re-imagining of Myspace, exploring ways in which the site has been positioned as an idealized social media platform, particularly in terms of technological skill development.

The fourth contribution focuses on YikYak in considering why some anonymous platforms that are prone to cyberbullying, copyright infringement, and hate speech survive while others die, despite the safe harbor status afforded to Internet Service Providers (ISPs) and social media platforms by Section 230 of the Communications Decency Act (CDA).

The fifth and final contribution included in the panel offers a case study of Couchsurfing to situate ways in which certain platforms become 'death stars' (Scholz, 2016), creating 'kill zones' that suffocate emerging competition in technological markets. 
Together, these arguments draw on single episodes of death to reveal entanglements between technologies, people, and markets that outlast and reverberate beyond the rise and fall of any single community.

\section{References}

Baym, N. (2015). Personal connections in the digital age. Cambridge, UK: Polity Press.

Belleflamme, P., \& Neysen, N. (2017). The rise and fall of Take Eat Easy, or why markets are not easy to take in the sharing economy. DigiWorld Economic Journal, (108).

Burgess, J., \& Green, J. B. (2009). YouTube: Online video and participatory culture. Cambridge, MA: Polity Press.

Chun, W. H. K. (2016). Updating to remain the same: Habitual new media. Cambridge, MA: MIT Press.

Gillespie, T. (2018). Custodians of the Internet: Platforms, content moderation, and the hidden decisions that shape social media. New Haven, CT: Yale University Press.

Gomez-Meijia, G. (2018). La fabrique de la désuétude. Regards diachroniques sur Geocities et Myspace. In V. Schafer (Ed.), Temps et Temporalités du Web, (pp. 77-88). Nanterre: Presses Universitaires de Nanterre.

Helmond, A., \& van der Vlist, F. N. (2019). Social media and platform historiography: Challenges and opportunities. Tijdschrift voor Mediageschiedenis, 22(1), 6-34.

Kircher, M. M. (2016, October 28). How Vine created a culture and lost control of it. New York Magazine. Retrieved from https://nymag.com/intelligencer/2016/10/vine-star-loganpaul-and-teens-talk-about-the-death-of-vine.html

Lee, K-S. (2017). Amplifying cyberactions: A short history of e-resistance in South Korea. In G. Goggin \& M. McLelland (Eds.), The Routledge Companion to Global Internet Histories, (pp. 505-515). London: Routledge.

Marvin, C. (1988). When old technologies were new. New York, NY: Oxford University Press.

Pearce, C. (2011). Communities of play: Emergent cultures in multiplayer games and virtual worlds. Cambridge: MIT Press.

Scholz, T. (2016). Platform Cooperativism. Challenging the Corporate Sharing Economy. http://www.rosalux-nyc.org/wpcontent/files_mf/scholz_platformcoop_5.9.2016.pdf 
Stevenson, M. \& Robert W. Gehl (2019). "The Afterlife of Software." In: A Networked Self: Birth, Life, Death, ed. Zizi Papacharissi. Routledge.

\section{PLATFORM LIFE, PLATFORM DEATH: COUNTER-HISTORIES OF MILITARY-MADE SOCIAL MEDIA}

Muira McCammon

Annenberg School for Communication, University of Pennsylvania

While many emerging histories of the web have attempted to study how people remember disappeared or deactivated websites (Yang and Wu, 2017), most have thus 
far dwelt on how big and still-existing platforms, such as Craigslist, Twitter, YouTube and Facebook, (Brügger, 2015; Lingel, 2020; Arceneaux \& Schmitz Weiss, 2010; Burgess \& Green, 2018;) have evolved. One aspect of Internet history that has not received much scholarly attention is how governments have tried and failed to create their own public social media platforms. Another aspect of Internet history that has not been studied much is how narratives and counter-narratives emerge, ebb, flow, and even vary during a platform's life and death.

In this article, I twin these two gaps in the scholarship by considering platform counternarratives and platform counter-memories. While a small sub-section of memory scholars has begun to grapple with the ways in which people remember disappeared, de-activated, and defunct platforms, much of this literature has avoided recognizing the power of counter-history or the potential of certain actors tied to a platform as counterstorytellers. Many memory narratives about the web that was are obtained through interviews, oral histories, technobiographies (Kennedy, 2003), but there is a tendency of many such studies to focus nostalgically and narratively on what has been lost in a platform's death instead of which stakeholders and power struggles facilitated its demise.

One aspect that communication historians tend to highlight in their origin stories of the Internet is the role that the U.S. military played in imagining and creating network infrastructures in the $20^{\text {th }}$ century (Levine, 2019). Yet, the $21^{\text {st }}$ century has posed a challenge to the U.S. military, which has stemmed from the privatization of much of the web and the rise of private social media companies. In his own official narrative of the U.S. military's engagement with digital platforms, Major General John Davis, the Pentagon's military cyber security adviser, explains that the rise of privately-owned network infrastructures has made it so that military cybersecurity "is not getting any easier because our reliance on key networks and systems that are not directly under DOD's control" (cited in Harris, 2019).

Today, a new wave of platform studies attempts to grapple with a different genre of stories told about new media: counter-narratives. In 'Opening to the original contributions: Counter-narratives and the power to oppose', Molly Andrews broadly defines counter-narratives as "the stories which people tell and live which offer resistance, either implicitly or explicitly, to dominant cultural narratives" (Andrews 2004, p. 1). Telling a story that conflicts with master narratives can lead to a subversive strategic positioning of the self. Bamberg (2005) defines a master narrative as a "preexistent sociocultural form of representation" meant to "delineate and confine local interpretation strategies and agency constellations in individual subjects as well as social institutions" (p. 287). This notion of counter-narrative is also largely intertwined with counter-memory, which George Lipsitz defines:

Counter-memory is a way of remembering and forgetting that starts with the local, the immediate, and the personal. Unlike historical narratives that begin with the totality of human existence and then locate specific actions and events within that totality, counter-memory starts with the particular and the specific and then builds outward towards a total story. Counter-memory looks to the past for the 
hidden histories excluded from dominant narratives. But unlike myths that seek to detach events and actions from the fabric of any larger history, counter-memory forces revision of existing histories by supplying new perspectives of the past...Counter-memory focuses on localized experiences with oppression, using them to reframe and refocus dominant narratives purporting to represent universal experience. (Lipsitz 1990, p. 213)

Lipsitz's framework situates counter-memory as "a way of remembering and forgetting that starts with the local, the immediate, and the personal" (p. 213). In Lipsitz's words, it "grapples with tensions between grand historical narratives and lived experience" ( $p$. 214). We can think of platform counter-memories as ways of reimagining and reconfiguring the influence of the state and the official on the user and the civilian.

Many counter-narratives have emerged on platforms, but only a small number of scholars have written counter-narratives of platforms. Pasquale (2016) uses the framework of the counter-narrative to discuss ways in which platform capitalism further creates occupational inequalities by disempowering workers through the auctioning of skills and reinforces systemic discrimination through ratings systems. I add to this corpus of work by considering the role and need for counter-memories, which emerge long after a platform's death and teach us about the continued power struggles existing between civilian and military stakeholders trying to imagine, design, and negotiate, among themselves, who will wield control over the future Internet.

This article offers an analysis of the narratives and counter-narratives that have developed around a government-initiated platform and the counter-memories that feed these understandings of the web that was; it traces the framing of a now barely invisible digital product. It deploys archaeological principles of excavation and analysis to a largely invisible digital terrain. To facilitate this study, I use a range of sources to think through where platform counter-narratives emerge after a platform fails. I draw on semistructured interviews with designers and users of the platform $(n=10)$, as well as military personnel, who were using various social media platforms during its life but chose not to use it $(n=5)$. Interviews were conducted in 2019, 2020, and 2021. I also rely on secondhand sources, from blogs posts to coverage in U.S. media. Looking across these different sources, I concentrate not only where platform counter-narratives emerge but how they contrast with platform narratives that were published during the platform's existence. Drawing on this data, I reveal how official military narratives about TroopTube obfuscated the counter-narratives that would emerge years later, that predicted the platform's frailty, fragility, and ultimate inability to compete against Big Tech.

\section{References}

Andrews, M. (2004) Counter-narratives and the power to oppose. In M. Bamberg and M. Andrews, Considering counter narratives: Narrating, resisting and making sense, (pp. 1-6). Amsterdam: John Benjamins. 
Arceneaux, N., \& Schmitz Weiss, A. (2010) Seems stupid until you try it: Press coverage of Twitter, 2006-9. New Media \& Society, 12(8), 1262-1279.

Bamberg, M. (2004). Considering counter narratives. In M. Bamberg and M. Andrews, Considering counter narratives: Narrating, resisting and making sense, (pp. 351-71). Amsterdam: John Benjamins.

Burgess, J., \& Green, J. (2018). YouTube: Online video and participatory culture. Cambridge, MA: Polity Press.

Brügger, N. (2015). A brief history of Facebook as a media text: The development of an empty structure. First Monday, 20(5).

Harris, Shane. (2014). @WAR : The rise of the military-internet complex. Boston: Houghton Mifflin Harcourt.

Kennedy, H. (2003). Technobiography: researching lives, online and off. Biography 26(1): 120-139.

Levine, Y. (2019). Surveillance valley: The secret military history of the Internet. New York: Public Affairs.

Lingel, J. (2020). An Internet for the people: The politics and promise of craigslist. Princeton, NJ: Princeton University Press.

Lipsitz, G. (1990). Time passages: Collective memory and American pop culture. Minneapolis, MN: University of Minnesota Press.

Yang, G., \& Wu, S. (2018). Remembering disappeared websites in China: Passion, community, and youth. New Media \& Society, 20(6), 2107-2124. 


\title{
THE MICROBLOG REVOLUTION THAT WASN'T: RECOUNTING THE RISE AND DEMISE OF FANFOU (2007-2020) UNDER CHINA'S CHANGING POLITICS
}

\author{
Lotus Ruan \\ University of Toronto, Canada
}

How does China's regulatory environment affect the development and evolution of niche social media platforms? How do small and surviving platforms and their users adjust their operation strategies and social media use in response to state control? This paper examines the state-business-society relationship displayed in Fanfou, China's first microblogging platform launched in 2007.

The development, influences, and political impacts of social media platforms have attracted much scholarly attention (Zhuravskaya et al., 2020). From the early-day optimism of the liberalising potentials of the Internet and social media (Barlow, 1996) to recent critiques of the data-based surveillance capitalism of platforms (Deibert, 2019; Fraser, 2020; Marciano et al., 2020; Zuboff, 2019), most of the literature on platform politics is derived from observations of Big Tech Western platforms including Facebook and Twitter (Jackson et al., 2020; Vaidhyanathan, 2018). In reality, however, Internet platforms are regional and context-specific (Steinberg \& Li, 2017; W. Y. Wang \& Lobato, 
2019). In this regard, the history of the Internet in China, or "the Chinese Internet" as (Yang, 2012) calls it, remains largely understudied despites calls for it (Zhao, 2009). Among studies that examine Chinese platforms, much is concerned with Big Tech in China such as Weibo (China's Twitter-like microblogging service) and WeChat (China's WhatsApp-like social networking app) (e.g., Jia \& Han, 2020; S. I. Zhang, 2020). Although these studies provide useful insights into the state-market relations in China, it is not clear whether these observations hold true for small, niche, and surviving platforms and digital communities.

Similarly, while a body of literature has been dedicated to recounting the success and struggles of Chinese Big Tech platforms and analyze when they capitulate to or resiststate control (Gallagher \& Miller, 2019; Han, 2018; Ng, 2015; Yang, 2009), little has been done to narrate the rise and demise of small platforms under China's political environment. Yet, as Yang \& Wu (2018) demonstrate, small platforms and disappeared websites provide an important "entry point" (p. 2109) into the ebbs and flows of Chinese platforms and yield fruitful knowledge of the characteristics of the Chinese Internet writ large. Moreover, resistance tactics by different actors often reflect and respond to changes of repression modes by the state (Boudreau, 2004). Whereas the Chinese state's targets and mechanisms of online repression remain erratic (Crandall et al., 2013; Jeffrey Knockel et al., 2017; Link, 2002), private actors and disgruntled citizens still "anticipate state activities, search out its pattern, and in light of that pattern, calibrate movement practice to navigate between the innocuous and the suicidal" (Boudreau, 2004, p.3). The everyday practices of Chinese Internet users, including their adjustment of online expressions and social media use, therefore "carry the burdens of historical memories and present concerns" (Yang, 2012, p. 51).

Positioned at the intersections of the scholarship on contentious politics in authoritarian regimes, platform governance, and web history, this study used process tracing and document analysis and identified the dominating role of the state in the rise and demise of Fanfou, China's once most influential public platform. A survey of individual narratives was also conducted to further the understanding of the dynamic state-business-society manifested throughout the development and evolution of Fanfou. This paper shows that Fanfou has opted for a much cautious approach to platform governance and become a closed community as a survival strategy after a series of political clampdowns and an increasingly restrictive political space. Fanfou users, who have imagined their own community, consciously chose to depoliticize the platform based on their past experience, understanding and anticipation of state repression to protect the platform from state control. Although this study, relying on one case study, is small in scope, it is the first attempt to examine the impacts of state control through the lens of small Chinese platforms and their users. It also adds to the study of "Histories of the Internet" (Haigh et al., 2015).

\section{References}

Barlow, J. P. (1996). A Declaration of the Independence of Cyberspace. 
Boudreau, V. (2004). Resisting Dictatorship: Repression and Protest in Southeast Asia. Cambridge University Press.

Crandall, J. R., Crete-Nishihata, M., Knockel, J., McKune, S., Senft, A., Tseng, D., \& Wiseman, G. (2013). Chat program censorship and surveillance in China: Tracking TOM-Skype and Sina UC. First Monday. https://doi.org/10.5210/fm.v18i7.4628

Deibert, R. J. (2019). Three painful truths about social media. Journal of Democracy, 30(1), 25-39. https://doi.org/10.1353/jod.2019.0002

Fraser, M. (2020). Big Trouble for Big Tech. New Labor Forum, 29(1). https://doi.org/10.1177/1095796019891155

Gallagher, M., \& Miller, B. (2018). The Progression of Repression: When does online censorship move toward real world repression?

Gallagher, M., \& Miller, B. (2019). Who Not What.

Gillespie, T. (2018). Custodians of the Internet: Platforms, Content Moderation, and the Hidden Decisions that Shape Social Media. Yale University Press.

Goldsmith, J., \& Wu, T. (2006). Who Controls the Internet? Illusions of a Borderless World. Oxford University Press.

Haigh, T., Russell, A. L., \& Dutton, W. H. (2015). Histories of the Internet: Introducing a Special Issue of Information \&amp;amp; Culture. Information \& Culture: A Journal of History, 50(2). https://doi.org/10.1353/lac.2015.0006

Jackson, S. J., Bailey, M., \& Welles, B. F. (2020). \#HashtagActivism Networks of Race and Gender Justice. MIT Press.

Jia, L., \& Han, X. (2020). Tracing Weibo (2009-2019): The commercial dissolution of public communication and changing politics. Internet Histories, 4(3), 304-332. https://doi.org/10.1080/24701475.2020.1769894

Keller, J. (2010, June 18). Evaluating Iran's Twitter Revolution. The Atlantic.

Knockel, J., Ruan, L., \& Crete-Nishihata, M. (2017). Measuring decentralization of Chinese keyword censorship via mobile games. 7th USENIX Workshop on Free and Open Communications on the Internet, FOCI 2017, Co-Located with USENIX Security 2017.

Marciano, A., Nicita, A., \& Ramello, G. B. (2020). Big data and big techs: understanding the value of information in platform capitalism. European Journal of Law and Economics, 50(3). https://doi.org/10.1007/s10657-020-09675-1 
McLelland, M., \& Goggin, G. (Eds.). (2019). The Routledge Companion to Global Internet Histories. Routledge.

Parmelee, J. H., \& Bichard, S. L. (2013). Politics and the Twitter Revolution: How Tweets Influence the Relationship Between Political Leaders and the Public. Lexington Book.

Pasquale, F. (2018). Tech Platforms and the Knowledge Problem.

Roberts, M. E. (2018). Censored: Distraction and Diversion Inside China's Great Firewall. Princeton University Press.

Vaidhyanathan, S. (2018). Antisocial Media: How Facebook Disconnects Us and Undermines Democracy. Oxford University Press.

van Dijck, Jose. (2014). Datafication, dataism and dataveillance: Big Data between scientific paradigm and ideology. Surveillance \& Society, 12(2).

https://doi.org/10.24908/ss.v12i2.4776

van Dijck, José, \& Poell, T. (2013). Understanding Social Media Logic. Media and Communication, 1(1). https://doi.org/10.17645/mac.v1i1.70

Wagner-Pacifici, R. (1996). Memories in the making: The shapes of things that went. Qualitative Sociology, 19(3). https://doi.org/10.1007/BF02393274

Yang, G. (2009). The Power of the Internet in China: Citizen Activism Online. Columbia University Press.

Yang, G. (2012). A Chinese Internet? History, practice, and globalization. Chinese Journal of Communication, 5(1). https://doi.org/10.1080/17544750.2011.647744

Yang, G., \& Wu, S. (2018). Remembering disappeared websites in China: Passion, community, and youth. New Media and Society, 20(6), 2107-2124.

https://doi.org/10.1177/1461444817731921

Zhao, Y. (2009). Communication in China: Political Economy, Power, and Conflict. Rowman \& Littlefield Publishing Group.

Zhuravskaya, E., Petrova, M., \& Enikolopov, R. (2020). Political Effects of the Internet and Social Media. https://doi.org/10.1146/annurev-economics

Zuboff, S. (2019). Surveillance Capitalism and the Challenge of Collective Action. New Labor Forum, 28(1). https://doi.org/10.1177/1095796018819461 


\title{
"TOM HAD US ALL DOING FRONT-END WEB DEVELOPMENT": A NOSTALGIC (RE)IMAGINING OF MYSPACE
}

\author{
Kate Miltner \\ University of Edinburgh, United Kingdom \\ Ysabel Gerrard \\ University of Sheffield, United Kingdom
}

On February 18, 2021, Twitter user Miss Bae (@yungskuntebony) Tweeted, "We took MySpace for granted, music on ur profile and no discourse that's all we needed". The Tweet quickly went viral, receiving over 141,000 likes and 21,000 retweets in less than a week. Although the velocity with which the Tweet spread was remarkable, the nostalgic sentiments that wistfully frame MySpace in comparison to contemporary social media are not new and have seen considerable growth in recent years-indeed, there were almost 6,000 nostalgic Tweets about MySpace in 2020 alone.

Founded in 2003, MySpace has cemented its place in the cultural imagination like few other social media platforms. Within three years of its launch, MySpace became the most visited website in the United States (Cashmore, 2006). Writing at the height of MySpace's popularity, Jones et al (2008) noted that the site's "flexibility" was a "significant element of its popularity".

However, by 2009 , competing social networking site Facebook surpassed MySpace in both global and U.S. traffic (Albanesius, 2009), becoming and remaining the dominant Western social network. At the peak of its decline, MySpace was largely seen by white elites as an amateurish "ghetto" where children were at risk of victimization (e.g., boyd, 2011) and portrayed as a "junk heap of bad design" (Parker quoted in Tsotsis, 2011) that reflected the racialized, gendered, and classed tastes of its least desirable users (boyd, 2011). While MySpace still exists today, it is broadly seen as a "dead" platform (Solon, 2018).

Although MySpace fell from dominance over a decade ago, the site has been nostalgically reframed in a way that positions it as an idealized social media platform, particularly in 
terms of technological skill development. One potent representation of this nostalgic reimagining is through Tweets about MySpace and computer programming skills. Niemeyer (2014) explains that, more than a trend or fashion, nostalgia is often related to imagining and (re)inventing the past, present, and future (p.2). Taking inspiration from Niemeyer's provocation, "what is nostalgia doing?" (ibid.), we ask, how should we make sense of the persistence and popularity of Tweets about MySpace and coding?

\section{Research methods \& ethical considerations}

To find a broad range of Tweets addressing MySpace nostalgia, we used the Web Data Research Assistant (WebDataRA) tool to collect Tweets using the search terms "MySpace" + "code", "coding", "coder", "coded" and "HTML". The earliest Tweets reflecting MySpace nostalgia appeared in 2012; due to the sheer volume of the dataset, we employed a sampling strategy that collected all Tweets returned by the aforementioned search terms every January from 2012-2021. After cleaning the data and removing 668 irrelevant Tweets, our corpus comprised a total of 2,305 Tweets. These Tweets were inductively and iteratively coded using thematic analysis (Guest et al, 2012; Gibson \& Brown, 2009). To protect the privacy of the users in our dataset, we employed fabrication (Markham, 2012) to construct representative interactions without the reproduction of exact language that may be searchable and traceable. The only Tweets we did not fabricate were "viral" Tweets with thousands of likes and retweets; these we attributed to their original authors.

\section{Research findings \& contributions}

Our thematic analysis of the dataset revealed three dominant trends within the dataset: 1.) general nostalgia, which focused largely on missing MySpace and reminiscing nostalgically about its features, particularly around customizability; 2.) skills, which suggested that MySpace was a place for skill development, particularly "coding" and HTML, often developed during a person's youth; and 3.) platform politics, where the nostalgia for MySpace was often oppositional in the sense that MySpace was seen as a "purer" alternative to untrustworthy modern platforms like Facebook. The dominant themes within these Tweets varied little from year to year and frequently overlapped; this cohesion suggests that these Tweets represented a distinct discourse-what we call the MySpace nostalgia discourse.

We argue that the MySpace nostalgia discourse is connected to the emergence of a broader coding fetish (Miltner, 2019) that positions computer programming as essential for individual access to the most desirable and highly paid labor markets, particularly for minoritized groups such as women and people of color. MySpace users needed to learn basic HTML and CSS to creatively modify their profiles, affordances that are mostly absent from contemporary social media platforms; this skill acquisition is now being framed as MySpace's "coding legacy" (Codecademy, 2020). We further contend that MySpace nostalgia is also rooted in dissatisfaction with the contemporary social media landscape: platforms with fixed identity and profiling architectures that prioritize individuals' monetizable behaviors rather than their creative self-expression. 
Collectively, the MySpace nostalgia discourse achieves two interrelated outcomes: First, it responds to the larger coding fetish discourse and re-imagines MySpace through the lens of digital skill development, reinforcing the framing of coding as a net good for social mobility, particularly for women and/or people of color. Second, it offers trenchant critiques of platform capitalism (Srnicek, 2017) that position MySpace as a foil for "toxic" and "gentrified" social media environments. Contrary to previous popular framings of MySpace as an unsafe setting that allowed risky behaviors to flourish, particularly around child safety (Marwick, 2008), MySpace coding Tweets offer a generative reimagining of MySpace as a place where young people-- and girls and Black youth in particular-learned valuable skills. In doing so, these Tweets take the very elements that supposedly caused MySpace's decline - its "messy" (Dredge, 2015) design, and the dominance of people of color and young women - and reposition them at the core of MySpace's value and worth. Overall, what the Twitter instantiation of the MySpace nostalgia discourse offers us is an important reflection on how technologies' perceived value can shift dramatically in response to contemporary discourses.

\section{References}

Albanesius, C. (2009, 16 June). More Americans go to Facebook than MySpace. PC Mag. Available at: https://www.pcmag.com/article2/0,2817,2348822,00.asp.

boyd, d. (2011). White flight in networked publics. How race and class shaped American teen engagement with MySpace and Facebook. In L. Nakamura \& PA Chow-White (Eds.), Race after the Internet, 203-222.

Cashmore, P. (2006, 11 July). MySpace, America's number one. Mashable. Available at: https://mashable.com/2006/07/11/myspace-americas-numberone/?europe=true\#7X596 tOZ5qR.

Codecademy. (2020, 14 February). MySpace and the coding legacy it left behind. Available at:https://news.codecademy.com/myspace-and-the-coding-legacy/.

Dredge, S. (2015, 6 March). MySpace - what went wrong: "The site was a massive spaghetti-ball mess". The Guardian.

https://www.theguardian.com/technology/2015/mar/06/myspace-what-went-wrong-seanpercival-spotify

Gibson, W.J. and Brown, A. (2009). Working with qualitative data. Thousand Oaks, CA: Sage.

Guest, G., MacQueen, KM and Namey, EE. (2012). Applied thematic analysis. Thousand Oaks, CA: Sage.

Jones S., Millermaier, S., Goya-Martinez, M. and Schuler, J. (2008). Whose space is MySpace? A content analysis of MySpace profiles. First Monday. 13(9). 
Markham, A. (2012). Fabrication as ethical practice: qualitative inquiry in ambiguous internet contexts. Information, Communication and Society. 15(3): 334-353.

Marwick, A. E. (2008). To catch a predator? The MySpace moral panic. First Monday.

Miltner, K.M. (2019). Anyone can code? The coding fetish and the politics of sociotechnical belonging. (Unpublished doctoral thesis). University of Southern California, Los Angeles, USA.

Niemeyer, K. (2014). Media and nostalgia: yearning for the past, present and future. Houndmills, Basingstoke, Hampshire: Palgrave Macmillan.

Srnicek, N. (2017). Platform capitalism. John Wiley \& Sons.

Tsotsis, A. (2011, 11 July). Sean Parker on why MySpace lost to Facebook.

TechCrunch. Available at: https://techcrunch.com/2011/06/28/sean-parker-on-whymyspace-lost-to-facebookl. 


\section{"YAKETY YAK, DON'T TALK BACK": MODERATION ON ANONYMOUS PLATFORMS}

Kathryn Montalbano

Appalachian State University, United States of America

Through an analysis of survey responses distributed to a subreddit, r/yikyak, as well as a broader community on Facebook and Twitter, this paper considers why some anonymous platforms that are prone to cyberbullying, copyright infringement, and hate speech survive while others die, despite the safe harbor status afforded to Internet Service Providers (ISPs) and social media platforms by Section 230 of the Communications Decency Act (CDA). Drawing from the conference theme, independence, Section 230 has granted ISPs and social media platforms the independence, so to speak, to develop and grow without the threat of libel, privacy, or copyright lawsuits based on the speech or actions of their users. The justification for minimal regulation of ISPs stems from the repeal of Title $\mathrm{V}$ of the Telecommunications Act of 1996-the overly broad Communications Decency Act (CDA). The Supreme Court ruled the act unconstitutional in Reno v. ACLU (1997) for including all forms of Internet indecency in its scope rather than narrowly tailoring regulation to apply to cases of minors. The Court rejected the idea that the Internet was analogous to a broadcaster that deserved less constitutional protection. Though Title V was struck down, Section 230 of the Communications Decency Act survived. Following this repeal, the argument follows, developers and policymakers were able to conceptualize and build the Internet as we know it today due to the protections Section 230 granted to ISPs and other digital platforms.

And yet, Internet culture and use has evolved significantly since 1996 when Section 230 was born, as the distinction between the online and offline worlds has become less clear. As Sylvain (2019, p. 272) has argued: "Today, however, intermediaries are far more than simple publishers or distributors of third-party content. And users appear to have few constraints on what they are willing to post or consume." Sylvain's argument stems from a critique of Wu (2019), who argues that automated systems may replace humans in adjudicating social media moderation. In the past year, policymakers and politicians have reconsidered the justification of Section 230's safe harbor status that has allowed these platforms to evolve independently of the constant threat of lawsuits. ISPs and social media platforms, in turn, argue that their exceptionalism within media industries justifies this safe harbor protection and independence in order to continually innovate and flourish. As such, these platforms find the proposal of regulation in the form of a revised Section 230 to be unfeasible, refusing to recognize their interdependence upon the various components of communication law, including privacy, libel, and copyright. Inadvertently, as a result of the continual safe harbor status of Section 230, community moderators or members on various platforms have long responded to the absence of legal sanctions for their overarching host platform by forging their own links of interdependence among users to create systems of community moderation and accountability.

Sylvain (2019, p. 264) argues that human review will continue to triumph over automated moderation, at least in the absence of platform liability: "Human review is essential today 
because it confers a degree of legitimacy on the platforms' moderation choices." Previous scholarship has examined how regulations prohibit online speech or action that likely lead to legal issues (Van Dijck, 2013). Additionally, this author has argued that hyperlocal anonymous platforms do not solely hide behind Section 230 , and that surviving platforms instead combine (1) robust Terms of Service statements along with (2) specific community values or guidelines that are fortified by (3) a comprehensive monitoring system, in order to curb abusive behavior on their platforms.

Online anonymous communities that survive thus rely on a robust, rigorous moderation system comprising both moderators and regular users to promote civility and accountability within large, frequently populated communities. These survey responses from people who used to communicate on Yik Yak and/or continue to utilize existing anonymous platforms will aim to answer the first broader research question: why do some anonymous platforms survive while others die? The subsequent analysis will then answer the second research question: to what degree does civility and effective moderation compensate for the safe harbor status granted by Section 230 to anonymous platforms, a legal framework that shifts the burden of moderation onto both volunteer moderators and regular users?

The "free labor" (Terranova, 2000) involved in maintaining online platforms provides a critical window into why anonymous platforms survive while others perish. A second component of this argument draws from scholarship on feminist media studies and community labor. Baym has showed how audiences, specifically fandom communities in the worlds of soap operas (Baym, 2000) and independent music (Baym, 2007) "appropriate the affordances of the internet in order to build communities based on shared practices and meanings" (Baym, 2015, p. 1). Duffy (2016, p. 443), though more explicitly addressing content creators, nonetheless offers a fruitful term for this paper, "authenticity labour," which she has traced from the "narratives of authenticity and realness; the instrumentality of affective relationships; and entrepreneurial brand devotion" within this broader umbrella of "gendered forms of social media production." Nieborg and Poell (2018, p. 4279) add to this body of scholarship on labor and cultural capital, remarking that "while political economists are acutely aware of the labor issues that arise from platform- dependent cultural production, less attention is paid to how this translates into the transformation of cultural commodities." In tandem, these bodies of scholarship on digital labor, online community, content moderation, and Section 230 bolster the primary analysis of the survey responses to demonstrate why some anonymous platforms live while others perish-despite the independence and autonomy that Section 230 of the Communications Decency Act grants them.

\section{References}

Baym, N. K. (2000). Tune in, log on: Soaps, fandom, and online community. Thousand Oaks, CA: Sage. 
Baym, N. K. (2007). The new shape of online community: The example of Swedish independent music fandom. First Monday, 12(8). https://doi.org/10.5210/fm.v12i8.1978

Baym, N. K. (2015). Connect with your audience! The relational labor of connection. The Communication Review, 18(1), 14-22.

Duffy, B. E. (2016). The romance of work: Gender and aspirational labour in the digital cultures industries. The International Journal of Cultural Studies, 19(4), 441-457.

Nieborg, D. B., \& Poell, T. (2018). The platformization of cultural production: Theorizing the contingent cultural commodity. New Media \& Society, 20(11), 4275-4292.

Sylvain, O. (2019). Recovering tech's humanity. Columbia Law Review 119(7), 252-282. Terranova, T. (2000). Free labor. Social Text, 18(2), 33-58.

Van Dijck, J. (2013). The culture of connectivity: A critical history of social media. Oxford: Oxford University Press.

$\mathrm{Wu}, \mathrm{T}$. (2019). Will artificial intelligence eat the law? The rise of hybrid social-ordering systems. Columbia Law Review 119(7), 2001-2028.

\section{THE CHANGING ECOLOGY OF THE WEB AS SEEN FROM THE MARGINS: THE STRUGGLE OF COUCHSURFING}

Karolina Mikołajewska-Zając

Kozminski University, Poland / University of Queensland, Australia

Attila Márton

Copenhagen Business School, Denmark 
While most of the popular business literature puts forward digital platforms' 'blitzscaling' (Hoffman \& Yeh, 2018) as a virtue and an ideal new market players should follow, much of social science literature on 'platformization' (Helmond, 2015; Nieborg \& Helmond, 2019; van Dijck, 2020) or 'surveillance capitalism' (Zuboff, 2019) describes the leading platforms' effects in terms of hegemony and dependencies they orchestrate. Both streams largely focus on 'winners' that manage to install themselves as obligatory passage points and, by and large, share the assumption that once dominant, the Facebooks and the Googles become too big to fail, too big to regulate, and too big to die. At the same time, there is a growing recognition that platform leaders become 'death stars' (Scholz, 2016), creating 'kill zones' that suffocate emerging competition, stifle innovation, and impoverish the diversity of the Web as an information ecology. In a sense, death is looming from every corner. Most platforms fail (Yoffie et al., 2019) and big tech corporations may be challenged by even bigger, more lavishly funded ones. Alternative niches are few and far between. Wikipedia is a an exceptionally rare success, relying on volunteer contributions and donations (Jemielniak, 2014) and a symbiotic relationship with Google, feeding into Google's search index in return for more traffic (van Dijck, 2013). Craigslist, another exception, remains loyal to its mission of making just enough profits, prioritizing access to classifieds (Lingel, 2020), but that seems to hinge only on the goodwill of the company's owners.

Against this backdrop, we develop an ecological framework for studying smaller - dead, dying, surviving, or marginalized - platforms, suggesting that they are uniquely equipped to shed light on the changing ecology of the Web. Inspired by Gregory Bateson's 'ecology of mind' (Bateson, 2000), we pay attention to ecological connections and the 'success' of a platform as the ongoing ability to adapt to new contexts. Following that, survival as not only a matter concerning a seemingly discreet entity - a platform - but rather this unit as part of a bigger whole, a platform plus its environment. From that perspective, platforms' 'success' is a matter of interdependence and not exceptionalism.

Our case study is Couchsurfing (CS), a free hospitality exchange platform, launched in 2004. Today, Couchsurfing inhabits a small niche in the information ecology of the Web, which is, however, shrinking and, with the impact of Covid-19, threatened to disappear. At the same time, Airbnb, which is operating in the same domain and facing the same challenges of collapsing income and absent revenue, managed to raise $\$ 3.5$ billion, when it went public in December 2020. what is the state of the Web, as arguably the most important information ecosystem of contemporary society, when some of its inhabitants have to beg for money to survive while others are being flooded by investment money to stay alive? What can we infer about the state of the Web, if we pay attention to the small niches rather than the big winners?

Our research material encompasses a large collection of in-depth interviews with various stakeholders, including the founders, volunteers, employees, and participants (81 interviews); as well as ethnographic observations (among 'regular CS members as well as CS HQ) and a collection of documents, including the company's blog, videos from CS events, press articles, and archival material, as well as documents gifted by the informants, including legal documents and archived public CS forums.

The broader public may be aware of Couchsurfing's transformation from a non-profit to a venture capital-funded for-profit in 2011. But against the backdrop of a broader historic 
perspective, we argue, the entire CS's history has been turbulent and punctuated by several near-deaths. This, we argue, opens a window into theorizing the broader changes the Web went through after the dot-com boom. Influenced partly by the Internet's military roots and the notion of 'redundancy' (John, 2016), the Web was often conceived as a radically novel medium because of its generativity (Zittrain, 2008). We argue that Couchsurfing's struggles to respond to drastic changes in its environment are indicative of the growing specialization of the Web with a single operating objective, which is to profit from user growth and traffic.

It is due to these developments that CS had run out of options by the time its charity application was rejected. The ecology of the Web had changed by then; it was welcoming to the profit motive while marginalizing alternative ideas, motives, and platforms. Through its turbulences, CS has been depleting the goodwill of volunteers and its legitimacy as a charity. It is this depletion of resources other than capital investments and revenues and the erosion of the Web as an information ecosystem that comes with it, that is, in our view, illustrated by the history of Couchsurfing.

From the point of view of ecological research, this suggests a systemic loss of flexibility. Such a development charts a dire perspective for the Web's future potential to react to unforeseen changes. In tracing the history of Couchsurfing's near-deaths and revival efforts through an ecological lens, we remain attuned to the Web's rhythmic temporality and digital media's constant revision and reinvention of forms, whereby the new forms replacing the old ones, while appearing hegemonic, are at the same time becoming increasingly fragile (Karpf, 2020).

\section{References}

Bateson, G. (2000). Steps to an Ecology of Mind. University of Chicago Press.

Helmond, A. (2015). The Platformization of the Web: Making Web Data Platform Ready. Social Media + Society, 1(2), 1-11.

Hoffman, R., \& Yeh, C. (2018). Blitzscaling: The Lightning-Fast Path to Building Massively Valuable Companies. Crown Publishing Group.

Jemielniak, D. (2014). Common Knowledge? An ethnography of Wikipedia. Stanford University Press.

John, N. (2016). The Age of Sharing. Polity Press.

Karpf, D. (2020). Two provocations for the study of digital politics in time. Journal of Information Technology \& Politics, 17(2), 87-96.

https://doi.org/10.1080/19331681.2019.1705222

Lingel, J. (2020). An Internet for the people: The politics and promise of Craigslist. Princeton University Press. 
Nieborg, D. B., \& Helmond, A. (2019). The political economy of Facebook's platformization in the mobile ecosystem: Facebook Messenger as a platform instance. Media, Culture \& Society, 41(2), 196-218.

Scholz, T. (2016). Platform Cooperativism. Challenging the Corporate Sharing Economy. http://www.rosalux-nyc.org/wpcontent/files_mf/scholz_platformcoop_5.9.2016.pdf

van Dijck, J. (2013). The Culture of Connectivity. A Critical History of Social Media. Oxford University Press.

van Dijck, J. (2020). Seeing the forest for the trees: Visualizing platformization and its governance. New Media \& Society, 146144482094029.

https://doi.org/10.1177/1461444820940293

Yoffie, D. B., Gawer, A., \& Cusumano, M. A. (2019, May 29). A Study of More Than 250 Platforms Reveals Why Most Fail. Harvard Business Review. https://hbr.org/2019/05/astudy-of-more-than-250-platforms-reveals-why-most-fail

Zittrain, J. (2008). The Future of the Internet and How to Stop It. Yale University Press.

Zuboff, S. (2019). The Age of Surveillance Capitalism. Profile Books. 